\title{
LOCAL REVENUE AND SERVICES IN NIGERIA: THE CASE OF OGUN STATE LOCAL GOVERNMENTS
}

\author{
S.I. Okafor
}

\begin{abstract}
This paper examines the links between the financial resources of local governments and the availability of local services. It also examines the 'equalisation effect' of grants from higher levels of government on resource disparities between local government areas. It was found that intergovernmental (financial) transfers do not necessarily eliminate need-resource gaps in local government areas. The existence of these gaps, in spite of grants from higher levels of government, implies that the allocation of grants negates an important objective of intergovernmental transfers, viz. to adjust for disparities in fiscal capacity among local jurisdictions caused by variations in resources, tax bases and population.
\end{abstract}

\section{INTRODUCTION}

In many countries, the provision of public services is the primary responsibility of local states. Although these local states (as well as central governments) play an important role in the economic development of their respective territories, they are the main providers "... of goods and services which are either absent or not available to all in the workings, of the private sector". This is a reflection of "... the dramatic expansion of the public economy as governments have become increasingly drawn into the creation of welfare states". ${ }^{3}$ The role of the state in public provision is important because of the inability or unwillingness of the private sector to provide public goods and services, given the nature of these goods and services. 
Among other things, "public facilities (and the goods and services provided there from) are designed to effect some kind of redistribution of resources, or, at least, patch up some failure in the private market". ${ }^{4}$ Besides, in most cases, the benefits of public services cannot be restricted to the producers alone.

However, the ability of local states to fulfill this role is influenced by the resources available to them. As Knox has it, there is some "interdependence of local service provision, local needs and local resources with administrative and political boundaries....". In spite of the importance of local revenue in this regard, it has been observed that ".... no system of local finance seems likely to provide sufficient resources for needs to be met satisfactorily. Central equalisation schemes are thus absolutely essential if severe territorial inequalities are to be avoided". In this paper, we examine the links between local resources and the availability of selected local services. It also looks into the equalisation effect of grants from higher levels of government.

\section{LOCAL STATES IN NIGERIA'S FEDERAL STRUCTURE}

Local states are administrative units that have political and spatial jurisdiction on a less than national scale. In Nigeria, there are two types of local states, namely: states and local government areas. There are 31 of the former and 589 of the latter. Nigeria thus has a three-tier federal structure with the federal government at the centre, the state governments in-between and the local governments at the bottom. This paper is primarily concerned with local government areas and specifically examines the links between local resources and local services in Ogun State.

The distribution of responsibilities in Nigeria's federal system determines which level of government is responsible for what. These responsibilities fall into two categories, namely: concurrent responsibilities and exclusive responsibilities. The former are those responsibilities or functions that are shared by two or more levels of government, while the latter are those that are exclusive to specific levels of government. For example, such functions as educational and health-care provision belong to the concurrent list. Thus, all three levels of government in the federation participate in the provision of educational and health-care facilities and services. However, there are differences in the types of educational and health-care facilities provided by the different levels of government. Taking educational provision, for instance, the federal government concentrates primarily, but not solely, on tertiary education. The state governments concentrate primarily on secondary education, while the local governments play a role in primary education. This role is participatory as the Constitution requires that local governments are to participate in the provision and maintenance of primary education (as well as the provision and maintenance of health services). Nevertheless, the local governments receive substantial assistance from higher levels of government in this regard and this tends to inflate the financial outlays of the federal and state governments in respect of educational provision. Assistance is also received for other local services such 
as health care. In spite of these assistance, the emphasis, on tertiary, secondary and primary education facilities by the federal, state and local governments respectively is an important feature of service provision in Nigeria.

Where responsibilities are concurrent, local governments are usually responsible for lower-order facilities such as primary schools, dispensaries and rural feeder roads, among others. Even where responsibilities are exclusive to local governments, the facilities and services they are charged with are often of the lower-order type, that is to say services that are meant for local communities and relatively personal in nature. Examples include cemeteries, market places and motor parks. Thus, although local states are the main providers of public goods and services in Nigeria, the responsibility falls more on state governments than on local government. In fact, some important local services, such as housing and police, are outside the jurisdiction of the local government, the latter being an exclusive responsibility of the central state, i.e. Federal Government of Nigeria. Since local governments are meant to fulfill their constitutional responsibilities with the resources available to them, an examination of the structure of local government finance is pertinent. This will be done using Ogun State as a case-study.

\section{LOCAL GOVERNMENT FINANCE}

The federal government is the main source of funds for local governments all over the country, and the local governments in Ogun State are no exception. In Ogun State, the contribution of the federal government to local government revenues rose from $47.38 \%$ in 1979 to $49.18 \%$ in $1980 .{ }^{9}$ Table 1 sets out the sources of local government revenue in the state in 1979, the year for which complete records are available. Overall, grants from the federal government accounted for about $47 \%$ of total local government revenue in the state. Grants from the state government accounted for about $22 \%$ while the residual per percentage $(31 \%)$ represents the internally generated revenue of local governments. Its main components are fines and fees as well as local taxes and rates. The category labelled 'others' in the table includes investments, rents and general revenue. Less than one-third of the revenue of local governments was internally generated and this reveals the extent of dependence of local governments on higher levels of government.

However, this dependence varies from one local government area to another. Abeokuta LGA was the least dependent on federal and state government funds. It generated about $54 \%$ of its total revenue internally. At the opposite extreme, Ijebu-Remo LGA was the most dependent on grants from both the federal government and the state government. These grants accounted for about $85 \%$ of its total revenue. The details are set out in the last column of Table 1 which reveals that apart from Abeokuta LGA, Ifo/Ota LGA and Ijebu-Ode LGA, much less than one-third of the total revenue of each of the other LGAs was generated internally. Abeokuta LGA contains Abeokuta which is not only the largest city in the state (313,828 inhabitants in 1980), but plays the dual political role of state capital and local government 


\section{Annals of the Social Science Council of Nigeria, No.4, 1992.}

headquarters for Abeokuta LGA; Ijebu-Ode, the headquarters of Ijebu-Ode LGA, is the second largest city in the state $(114,855$ inhabitants in 1980), white both Ifo and Ota in Ifo/Ota LGA are important industrial centres. The political status of towns, level of urbanisation and level of industrial activity which is an important taxable activity in Nigeria, thus appear to influence

Table 1

MAIN SOURCES OF LOCAL GOVERNMENT REVENUE IN OGUN STATE (\%)

\begin{tabular}{|c|c|c|c|c|c|c|}
\hline$L G A^{*}$ & $\begin{array}{l}\text { Federal } \\
\text { Govt } \\
\text { Grants }\end{array}$ & $\begin{array}{l}\text { State } \\
\text { Govt } \\
\text { Grants }\end{array}$ & $\begin{array}{l}\text { Fines and } \\
\text { Fees } \\
\text { (a) }\end{array}$ & \begin{tabular}{|l} 
Taxes \\
and \\
Rates \\
(b)
\end{tabular} & $\begin{array}{l}\text { Others } \\
\text { (c) }\end{array}$ & $a+b+c$ \\
\hline Abeokuta & 31.60 & 14.58 & 21.07 & 27.64 & 5.11 & 53.82 \\
\hline $\begin{array}{l}\text { Egbado } \\
\mathrm{N} .\end{array}$ & 48.66 & 22.12 & 4.50 & 23.43 & 1.29 & 29.22 \\
\hline Egbado S. & 44.02 & 28.96 & 8.42 & 17.15 & 1.45 & 27.02 \\
\hline Ifo/Ota & 38.38 & 21.56 & 08.87 & 13.13 & 18.06 & 40.06 \\
\hline Ijebu East & 56.05 & 25.28 & 3.78 & 12.77 & 2.12 & 18.67 \\
\hline $\begin{array}{l}\text { Ijebu } \\
\text { North }\end{array}$ & 52.19 & 23.23 & 6.88 & 15.56 & 2.14 & 24.58 \\
\hline Ijebu-Ode & 43.32 & 20.37 & 18.23 & 13.23 & 4.75 & 36.31 \\
\hline $\begin{array}{l}\text { Ijebu- } \\
\text { Remo } \\
\text { Obafemi// } \\
\text { Owode } \\
\text { Odeda }\end{array}$ & $\begin{array}{l}67.59 \\
48.90\end{array}$ & $\begin{array}{l}17.11 \\
31.69\end{array}$ & 8.323 .82 & $\begin{array}{l}5.40 \\
10.18\end{array}$ & $\begin{array}{l}1.58 \\
5.41\end{array}$ & \begin{tabular}{|l|}
15.30 \\
19.41
\end{tabular} \\
\hline
\end{tabular}

Source: Idachabae/ al (1981)

*Local Government Area

the capacity of local government areas to generate revenue internally. What this boils down to is that LGAs that have concentrations of lucrative and taxable economic activities, as are usually found in urban-industrial complexes, generate substantial internal revenue.

Figure 1 depicts both the spatial distribution and the structure of local government revenue in the state. Abeokuta LGA received the largest total revenue. It is followed by IjebuRemo LGA, Egbado South LGA and Ijebu-Ode LGA, in that order. Odeda LGA had the smallest total revenue, much of it coming from the federal government. The other LGAs in which federal government grants constituted a substantial part of their total revenue were Egbado North, Egbado South, Obafemi/Owode, Ijebu-Remo, Ijebu North and Ijebu East. The question, then, is whether or not these grants helped lo 'equalise' resources for the LQAs. 
Local Revenue and Services in Nigeria: Ogun State LGAs 109

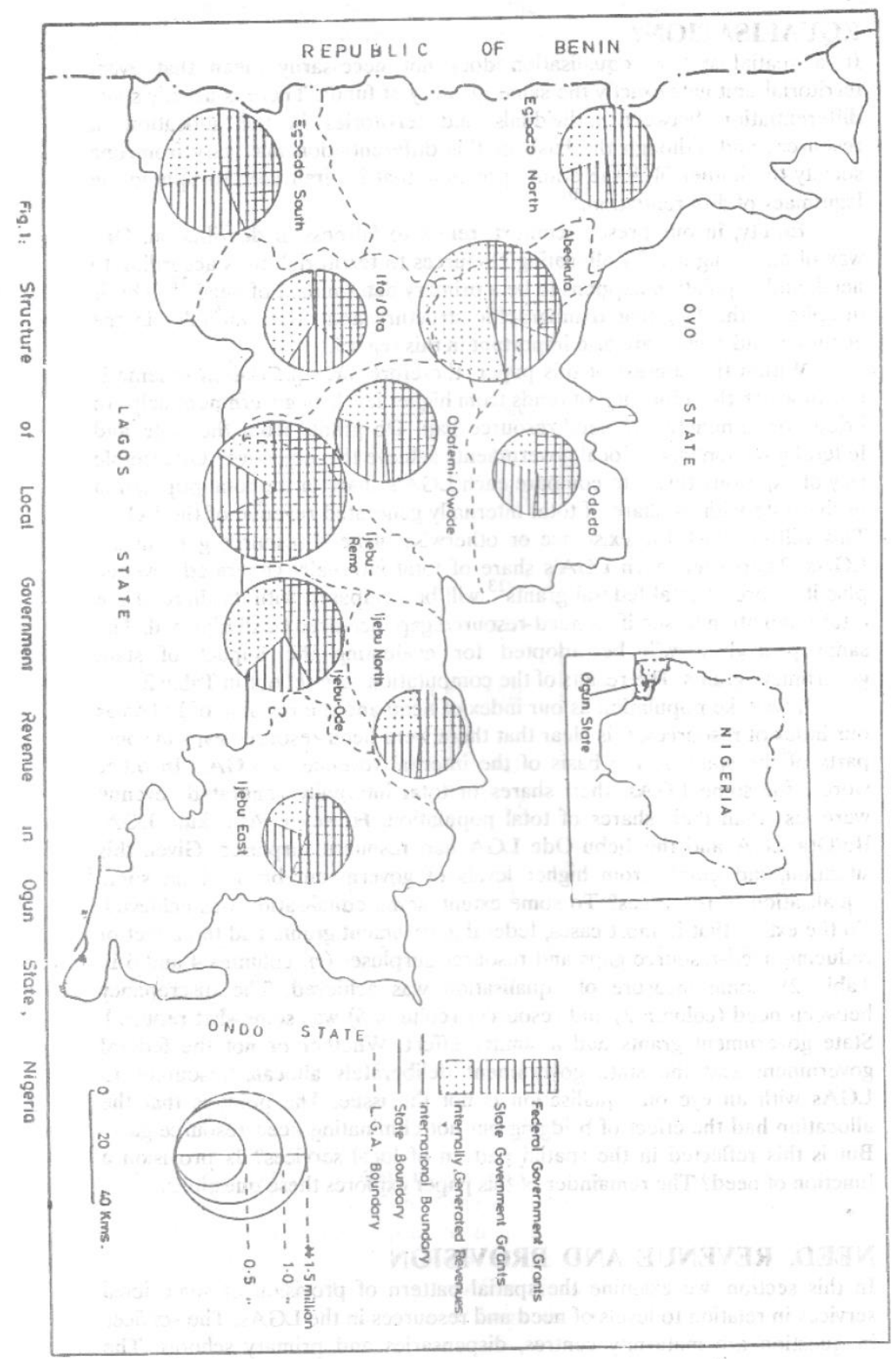




\section{Annals of the Social Science Council of Nigeria, No.4,1992.}

\section{EQUALISATION?}

In a spatial system, equalisation does not necessarily mean that every territorial unit gets exactly the same quantity of funds. There is usually some differentiation between individuals and territories in the allocation of resources and although the basis of this differentiation may vary from one society to another, it is the equity principle that is often used to uphold the legitimacy of differentiation. '

Equity, in our present context, refers to fairness in distribution. One way of achieving it is by allocating resources to territorial units according to need, and population happens to be a primary determinant of need. This is in spite of the fact that demographic structure and other variables in the economy and society are also important in this regard.

Within the context of this paper, therefore, an equalisation scheme is one in which the allocation of funds from higher levels of government helps to bridge or eliminate the needresource gap. Do grants from the state and federal governments to local governments achieve this objective? One simple way of exploring this is to compare each LGA's share of the total population of the state with its share of total internally generated revenue of the LGAs. This will establish the existence or otherwise of need-resource gaps in the LGAs. Thereafter, each LGA's share of total internally generated revenue plus its share of total federal grants will be compared with its share of the total population to see if its need-resource gap increased or diminished. The same procedure will be adopted for evaluating the impact of state government grants. The results of the computations are set out in Table 2 .

If we take population as our index of need and the revenue of LGAs as our index of resources, it is clear that there were need-resource gaps in some parts of the state on the basis of the internal revenue of LGAs. In other words, for some LGAs, their shares of total internally generated revenue were less than their shares of total population. However, Abeokuta LGA, Ifo/Ota LGA and the Ijebu-Ode LGA had resource surpluses. Given this situation, did grants from higher levels of government bring about some equalisation of resources? To some extent, some equalisation was achieved. To the extent that in most cases, federal government grants had the effect of reducing need-resource gaps and resource surpluses (c/. columns 4 and 6 in Table 2), some measure of equalisation was achieved. The discrepancy between need (column 2) and resources (column 5) was somewhat reduced. State government grants had a similar effect. Whether or not the federal government and the state government deliberately allocate resources to LGAs with an eye on equalisation is not the issue. The point is that the allocation had the effect of bridging but not eliminating needresource gaps. But is this reflected in the spatial pattern of local services? Is provision a function of need? The remainder of this paper explores these questions.

\section{NEED, REVENUE AND PROVISION}

In this section, we examine the spatial pattern of provision of some local services in relation to levels of need and resources in the LGAs. The services in question are maternity centres, dispensaries and primary schools. The 
Local Revenue and Services in Nigeria: Ogun State LGAs 111

emphasis on these services is dictated by the fact that in Nigeria, educational and healthcare services have had the greatest social impact because they are more widely available. In 1979, the year under review, there were

Table 2

NEED-RESOURCE GAPS IN THE LOCAL GOVERNMENT AREAS

\begin{tabular}{|c|c|c|c|c|c|c|c|}
\hline$L G A$ & $\begin{array}{l}\text { Popu- } \\
\text { lation } \\
\text { (a) }\end{array}$ & (b) & $a-b$ & $\begin{array}{l}I R+F G \\
\text { (c) }\end{array}$ & $a-c$ & $\begin{array}{l}I R \text {-f-SG } \\
(d)\end{array}$ & $\mathrm{a}-d$ \\
\hline Abeokuta & 15.6 & 31.5 & -15.9 & 19.6 & -4.0 & 23.2 & -7.6 \\
\hline $\begin{array}{l}\text { Egbado } \\
\mathrm{N} \text {. }\end{array}$ & 8.2 & 7.5 & 0.7 & 7.8 & 0.4 & 7.6 & 0.6 \\
\hline Egbado S. & 13.6 & 10.8 & 2.8 & 11.1 & 2.5 & 13.0 & 0.6 \\
\hline Ifo/Ota & 9.4 & 11.0 & -1.6 & 8.5 & 0.9 & 9.8 & -0.4 \\
\hline Ijebu East & 7.2 & 3.9 & 3.3 & 6.1 & 1.1 & 5.3 & 1.9 \\
\hline Ijebu N. & 7.6 & 5.5 & 2.1 & 6.7 & 0.9 & 6.2 & 1.4 \\
\hline Ijebu-Ode & 12.3 & 13.5 & -1.2 & 11.6 & 0.7 & 12.2 & 0.1 \\
\hline $\begin{array}{l}\text { Ijebu- } \\
\text { Remo } \\
\text { Obafemi// }\end{array}$ & 10.3 & 7.8 & 2.5 & 16.7 & -6.4 & 9.7 & 0.6 \\
\hline Owode & 8.6 & 5.1 & 3.5 & 7.1 & 1.5 & 7.8 & 08 \\
\hline Odeda & 7.2 & 3.5 & 3.7 & 4.9 & 2.3 & 5.1 & 2.1 \\
\hline Total & 100.0 & $100.1^{*}$ & & $100.1^{*}$ & & $99.9 *$ & \\
\hline
\end{tabular}

*Rounding errors

IR. Internally generated revenue

FG. Federal government grants

SG. State government grants

111 maternity centres, 133 dispensaries and 1,208 primary schools in the state. Table 3 sets out the distribution of these institutions among ten LGAs in the state. This distribution is represented in Fig.2 which depicts each LGA's share of the selected services against its shares of total LGA revenue and total population of the state. It is clear from the map that the LGAs with large populations do not necessarily have large shares of the public services in 
112 Annals of the Social Science Council of Nigeria, No.4, 1992

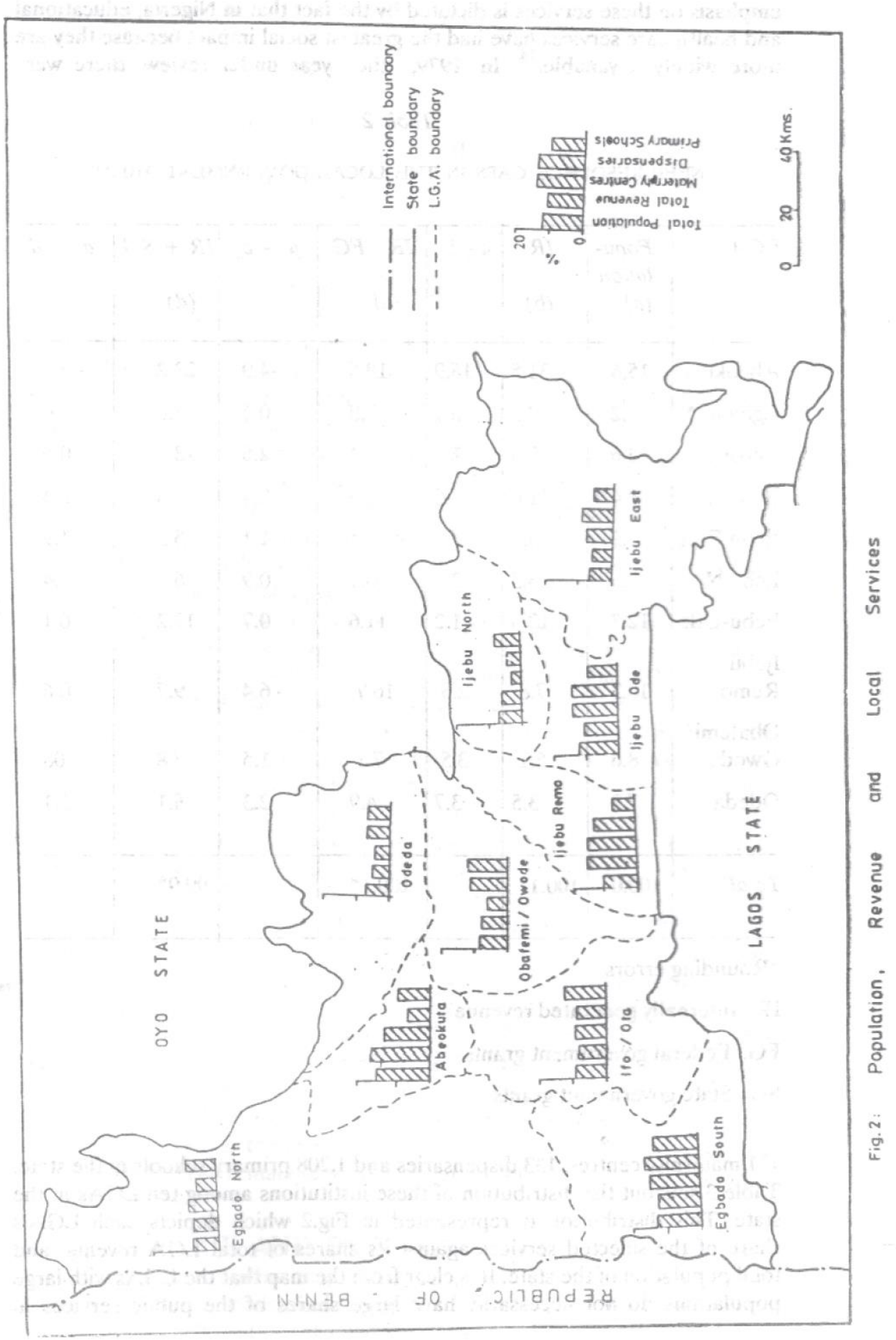


question; neither do the LGAs with small populations have correspondingly small shares of the public services. The same is true of revenue.

It may be argued that the demand for the public services in question is likely to vary according to the demographic and socio-economic characteristic

Table 3

\section{DISTRIBUTION OF SELECTED PUBLIC SERVICES}

\begin{tabular}{l|l|l|l|l|l|l}
\hline LGA & \multicolumn{2}{|l|}{$\begin{array}{l}\text { Maternity } \\
\text { Centres }\end{array}$} & \multicolumn{2}{|l|}{ Dispensaries } & \multicolumn{2}{l}{$\begin{array}{l}\text { Primary } \\
\text { Schools }\end{array}$} \\
\cline { 2 - 7 } & No. & $\%$ & No. & $\%$ & No. & $\%$ \\
\hline Abeokuta & 15 & 13.5 & 9 & 6.8 & 117 & 9.7 \\
EgbadoN. & 10 & 9.0 & 8 & 6.0 & 117 & 9.7 \\
Egbado S. & 17 & 15.3 & 22 & 16.5 & 165 & 13.7 \\
Ifo/Ota & 11 & 9.9 & 12 & 9.0 & 152 & 12.6 \\
Ijebu East & 9 & 8.1 & 13 & 9.8 & 102 & 8.4 \\
Ijebu North & 4 & 3.6 & 6 & 4.5 & 102 & 8.4 \\
Ijebu-Ode & 16 & 14.4 & 19 & 14.3 & 117 & 9.7 \\
Ijebu-Remo & 17 & 15.3 & 18 & 13.5 & 92 & 12.7 \\
Obafemi/Ow & 7 & 6.3 & 16 & 12.0 & 153 & 12.7 \\
ode & & & & & & \\
Odeda & 5 & 4.5 & 10 & 7.5 & 91 & 7.5 \\
\hline Total & 111 & $99.9 *$ & 133 & $99.9 *$ & 1203 & 100.0 \\
\hline
\end{tabular}

Source: Idachaba, et al (1981)

*Rounding errors

of the population, and not necessarily according to total population. For instance, primary school provision is somewhat dictated by the size of the primary school-age population. However, it has been suggested elsewhere that the demographic and socioeconomic characteristics of the Nigerian population do not vary significantly at the regional level. In fact, Arowolo ${ }^{15}$ has shown that the population pyramids for different spatial units in the country show a pronounced similarity in population structure. "This suggests that the proportion of different population sub.-groups or cohorts in the total population does not vary significantly from one spatial unit to another" ${ }^{1}$ and it obviates the need to rely on demographic and socio-economic statistics of doubtful accuracy.

The lack of congruence between population and provision, even for facilities that are meant for the entire populace, has been established at 


\section{Annals of the Social Science Council of Nigeria, No. 4,1992.}

different spatial scales. ${ }^{17}$ 1S There is thus some discrepancy between need and provision, and this is supported by the weak correlations between population and two of the public services in Table 4. There is, therefore, no substantial 'equalisation' of service provision. The slight equalisation of resources observed earlier on is thus reflected in the spatial pattern of local services.' Indeed, the coefficient of correlation between internally generated revenue, on the one hand, and grants from the Federal government $(r=0.23)$ and the state government $(r=$ 0.38) reveal a positive, even if weak, relationship between internal revenue and grants from higher levels of government. The positive signs indicate that LGAs with substantial internally generated revenue received more federal and state grants. Thus, although intergovernmental transfers can help to rectify disparities in tax bases among local jurisdictions, grants from higher levels of government do not appear to accord with this important principle in Ogun State.

Table 4

CORRELATIONS BETWEEN LOCAL SERVICES AND INTERGOVERNMENTAL TRANSFERS.

\begin{tabular}{l|l|l|l|l|l}
\hline Local Services & $\begin{array}{l}\text { Federal } \\
\text { Grants }\end{array}$ & $\begin{array}{l}\text { State } \\
\text { Grants }\end{array}$ & $\begin{array}{l}\text { Internal } \\
\text { Revenue }\end{array}$ & $\begin{array}{l}\text { Total } \\
\text { Revenue }\end{array}$ & $\begin{array}{l}\text { Total } \\
\text { Populati } \\
\text { on }\end{array}$ \\
\hline $\begin{array}{l}\text { Maternity } \\
\text { Centres }\end{array}$ & 0.70 & 0.73 & 0.55 & 0.82 & 0.73 \\
$\begin{array}{l}\text { Dispensaries } \\
\text { Primary }\end{array}$ & 0.47 & 0.76 & -0.05 & 0.34 & 0.25 \\
Schools & -0.20 & 0.54 & 0.14 & 0.06 & 0.22 \\
\hline
\end{tabular}

When it comes to the issue of provision vis-to-vis revenue, the picture that emerges is one in which internally generated revenue is weakly correlated with the selected public services, with the possible exception of maternity centres. In fact, maternity centres have comparatively high positive correlations with the revenue variables. Unlike the internal revenue of LGAs, federal and state grants generally have higher correlations with the public services. This indicates that LGAs with more local services received more grants from higher levels of government. Given the disparities between population and the provision of local services, these grants can hardly reduce territorial inequalities in service provision. Grants from the state government have higher correlations with the three local services in question. This is probably a reflection of the situation in the late 1970s, and early 1980s whereby the states in Nigeria appropriated many local responsibilities, including the collection of some local revenues.

The spatial distribution of primary schools confirms some important features of local public finance and local service provision in- Nigeria. A stepwise multiple regression model was employed in an effort to account for the spatial variations in the distribution of primary schools in Ogun State, 
Local Revenue and Services in Nigeria: Ogun Stale LGAs 115

using federal and state grants, internal revenue and the population of LGAs as the explanatory variables. The level of explanation achieved was about $74 \%\left(\mathrm{r}^{*}=0.73590\right)$, with federal and state grants responsible for about $66 \%$. In fact, federal grants constitute the most important variable in this regard, accounting for about $37 \%$ of the explanation. These details are set out in

\section{Table 5}

\section{FACTORS INFLUENCING THE DISTRIBUTION OF PRIMARY SCHOOLS}

\begin{tabular}{l|l|l|l|l}
\hline $\begin{array}{l}\text { Explanatory } \\
\text { Variables }\end{array}$ & $R^{*}$ & $\begin{array}{l}R^{*} \\
\text { Change }\end{array}$ & $B$ & $t$ \\
\hline State grants & 0.029049 & 029049 & 0.00056 & $2.9^{*}$ \\
Federal grants & 0.66268 & 037219 & -0.00007 & $2.3^{*}$ \\
Total population & 0.67643 & 0.01376 & -0.00042 & 1.1 \\
Internal revenue & 0.73590 & 0.05947 & 0.00012 & 1.1 \\
& & & & \\
\hline
\end{tabular}

-Significant at $5 \%$

Table 5. It is clear from the table that apart from their relatively small contributions to the level of explanation achieved by the model, the population and internal revenue variables are, in fact, not significant. This underscores the importance of intergovernmental transfers in the provision of local services It also underscores the fact that the provision of local services does not necessarily reflect spatial variation in need.

The role of grants in this particular case appears to be in line with World Bank thinking on this subject, which suggests that "... social services should be supported by grants". It argues that intergovernmental grants "are needed because the benefits or costs of public services provided by local governments can spill over to other jurisdictions. For example, ... one jurisdiction's education services contribute to a productive labour force that can migrate to other jurisdictions. Some local public services, especially social services, may have national and regional benefits as well". In Nigeria, however, these grants are not used for social services alone but also for other public services and utilities. The growing dependence of LGAs in Nigeria on grants from higher levels of government (especially from the Federal Government) bears testimony to this assertion. For example, in 1978, intergovernmental transfers accounted for 70:1\% of total local government revenue in the country while in 1983 , the proportion rose to $80.9 \%$.

\section{CONCLUSION}

The insufficiency of local finance for meeting local needs for services necessitates intergovernmental transfers in a bid to avoid severe inequalities 
in resource base and in service provision between spatial units. This paper has revealed that in spite of the existence of need-resource gaps in some LGAs in Ogun State, intergovernmental transfers only reduced but did not eliminate them. The existence of need-resource gaps in spite of these grants means that, in the final analysis, the grants do not address the fundamental issue of spatial inequalities in local finance and in local services. In fact, it was shown that the grants tend to be higher for better-served LGAs. Whatever the ownership of the local public services in Ogun State, the spatial structure of intergovernmental transfers, especially in relation to the spatial patterns of need and of the internal revenue of LGAs, cannot bring about an equitable distribution of local services,. It follows, therefore, that the allocation of grants negated an important objective of intergovernmental transfers which is to adjust for disparities in fiscal capacity among local jurisdictions caused by variations in resources, tax bases and population, and Ogun state could not have been alone in this situation. 
Local Revenue and Services in Nigeria: Ogun State LGAs 117

\section{REFERENCES}

1. Knox, P. and Agnew, J. (1989) Tlie Geography of the World Economy, London: Edward Arnold.

2. Coates, B. E.; Johnston, R. J. and Knox, P. L.(1977) Geography and Inequality, London: Oxford University Press.

3. Knox, P. and Agnew, J. (1989), op. cit.

4. Dear, M. J. (1974) "A paradigm for public facility location theory", Antipode 6(1), 46-50.

5. Knox, P. (1982) Urban Social Geography: An Introduction, London: Longman.

6. Coates et al (1977), op. cit.

7. Nigeria (1989) Constitution of the Federal Republic of Nigeria, Second Schedule..

8. Okafor, S. I. (1989) "The Population Factor in Public Service Provision in Nigeria", in Applied Geography, 9(2), 123-33.

9. Idachaba, F. S.; Umebese, C. E.; Akingbade, I. O. and Adeniyi, A. (1981) Rural Infrastructures in Nigeria: Basic Needs of the Rural Majority, Lagos: Federal Department of Rural Development.

10. Smith, D. M. (1977) Human Geography: A Welfare Approach, London: Edward Arnold.

11. Smith, D. M. (1979) Wtiere the Grass is Greener: Living In an Unequal World, London: Penguin.

12. Barnett, J. R. (1984) "Equity, access and resource allocation: planning hospital services in New Zealand", Social Science and Medicine, 18(11), 981-89.

13. This was obtained as follows: $\mathrm{IR}+\mathrm{FG}$

$$
\text { IR + FG x } 100
$$

where IR = Internal revenue

$\mathrm{FG} \quad=\quad$ Federal grants

14. Okafor, S. I. (1989), op. cit. 
118 Annals of the Social Science Council of Nigeria, No.4,1992.

15. Arowolo, O. (1982) "Demographic characteristics", in Barbour, K. M.; Oguntoyinbo, J. S.; Onyemelukwe, J.O.C. and Nwafor, J. C. (eds) Nigeria in Maps, London: Hodder and Stoughton.

16. Okafor, S. I. (1989), op. cit.

17. Okafor, S. I. (1987a) "Inequalities in the distribution of health-care facilities in Nigeria", in Akhtar, R. (ed) Health and Diseases in Tropical Africa: Geographical and Medical Viewpoints, London, pp.383-401.

18. Okafor, S. I. (1987b) "Jurisdictional partitioning, distribution policies and the spatial structure of health-care provision in Nigeria", Political Geography Quarterly, 6(4), 335-46.

19. World Bank (1988) "Paying the bills for urban services", The Urban Edge 12(6), 1-3.

20 Olowu, D. (1988) "Nigeria: Federal and State Transfers to Local Governments, 1970-1987", Background Paper,World Development Report, World Bank, Washington, D.C.

21. WDR (1988) World Development Report, London: Oxford University Press.

22. WDR (1988), op. cit

23. Olowu, D. (1988), op. cit.

24. WDR (1988), op. cit. 